\title{
Alteration in haematological and biochemical parameters of Catla catla exposed to sub-lethal concentration of cypermethrin
}

\author{
T. Vani $\cdot$ N. Saharan $\cdot$ S. D. Roy $\cdot$ \\ Ritesh Ranjan • A. K. Pal • G. M. Siddaiah • \\ Rajesh Kumar
}

Received: 21 September 2011/Accepted: 23 April 2012/Published online: 13 May 2012

(C) Springer Science+Business Media B.V. 2012

\begin{abstract}
A 60-day experiment was carried out to study the effect of sub-lethal concentration of cypermethrin (1/10th of $\mathrm{LC}_{50}$ ) exposure on haematological and biochemical parameters of the Indian major carp, Catla catla fingerlings. Under exposure, the total erythrocyte count, total leucocyte count, haemoglobin content and haematocrit were decreased. All the studied serum parameters viz. total serum protein, albumin, globulin contents and albumin-globulin ratio were significantly decreased in cypermethrin-exposed fishes. A marked increase was recorded in alanine aminotransferase and aspartate aminotransferase activities in liver, whereas lactate dehydrogenase activity of muscle and acetylcholine esterase activity in brain were inhibited in cypermethrin-exposed fish.
\end{abstract}

T. Vani $(\bowtie) \cdot$ N. Saharan · S. D. Roy

Aquaculture Division, Central Institute of Fisheries

Education (CIFE), 7 Bungalows, Versova, Andheri (W),

Mumbai 400061, India

e-mail: vanitgowda@gmail.com

R. Ranjan

Mariculture Division, VRC of CMFRI, Visakhapatnam 530003, India

\section{A. K. Pal · G. M. Siddaiah}

Fish Nutrition, Biochemistry and Physiology Division,

CIFE, Mumbai 400061, India

R. Kumar

Aquaculture Production \& Environment Division, CIFA, Bhubaneswar 751002, Orissa, India
The membrane transport enzymes (total adenosine triphosphatase, sodium-potassium adenosine triphosphatase and magnesium adenosine triphosphatase) activities were decreased significantly in the gills of C. catla exposed to sub-lethal concentration of cypermethrin. The present study indicates that sub-lethal exposure of $C$. catla fingerlings to cypermethrin alters the haematological and biochemical parameters.

Keywords Catla catla - Cypermethrin . Haematology $\cdot$ Biochemical parameters

\section{Introduction}

Pesticides have contributed considerably to the human welfare, but their residues often reach ecosystems causing undesirable impact. Hence, pesticides have become an increasingly serious source of chemical pollution to the environment due to their extensive usage in agriculture and public health protection programs. In the late 1970s, synthetic pyrethroid was successfully introduced into the agricultural market as a new generation of insecticides, owing much to their unique ability to kill insects instantly at lower application rates, lower mammalian toxicity and longer stability in outdoor environment.

Cypermethrin, RS- $\alpha$-cyano-3-phenoxybenzyl (1RS)cis-, trans-3-(2,2,-dichlorovinyl)-2,2-dimethylcyclopropanecarboxylate, is one among the synthetic pyrethroid 
insecticides that is extremely effective against a wide range of insect pests in agricultural and sanitary pest control. It is both stomach and contact poison (Jin and Webster 1998), which affect the nervous system of vertebrates and invertebrates by affecting voltage-dependent sodium channels (Vijverberg and van den Bercken 1990) and inhibiting ATPase enzymes (Siegfried 1993).

Cypermethrin is registered for use on a wide array of crops including cotton, cabbage, okra, brinjal, sugarcane, wheat and sunflower in India. Almost $70 \%$ of all sprays used on cotton in Andhra Pradesh in India are pyrethroids, which contain mostly cypermethrin (Jayswal 1989). In aquaculture also, cypermethrin is used against lice infestations in fish (Sommerville 1995; Hart et al. 1997; Braidwood and Hart 1998; Mukherjee et al. 2000). However, the residual cypermethrin, which is released directly into the environment, enters the water body through run-off and affects the aquatic ecosystem. The residual cypermethrin was found to be in the range of $0.001-0.035 \mu \mathrm{g} \mathrm{g}^{-1}$ in soil and $0.022-0.090 \mathrm{ppb}$ in the water of agriculture field in Haryana, India (Kumari et al. 2008).

The toxicity of pyrethroid insecticides to aquatic organisms, esp. fish, has received much attention in recent years. The exposures of cypermethrin alter the biochemical, haematological parameters and enzymes of organ tissue and exert stress on the fish (Das and Mukherjee 2003; Kumar et al. 2007). It also alters the several physiological parameters in caenorhabditis elegans (Shashikumar and Rajini 2010). Due to its lipophilic nature, cypermethrin has high rate of gill absorption, thereby rendering fish as most sensitive to this pesticide. Although it has been reported that cypermethrin toxicity is reduced under field conditions in water bodies with abundant particulate material (Hill 1989) and also no lethal effects have been observed after insecticide exposure under fielduse conditions (Carriquiriborde et al. 2007), concern exists about the possible sub-lethal effects induced by this pesticide; particularly taking into account that cypermethrin spraying events mainly occur during the breeding season of many fish species and also during stocking of fish seeds into aquaculture system.

The effects of pesticide pollution on non-target organisms (e.g. fish) in the environment can be studied by detecting changes in organisms at the physiological, biochemical or molecular levels, which can provide 'early warning' tools in monitoring environment quality (Crane and Maltby 1991; Miren et al. 2000). These sensitive early warning biomarkers can measure interaction between environmental xenobiotics and biological effects. Inhibition and induction of these biomarkers are a good approach to measure potential impacts of pollutants on environmental organisms (Rendon-von Osten et al. 2005). The analysis of haematological and biochemical parameters in fish can contribute to the assessment of the animal's health and also the habitat conditions (Thrall 2004).

Catla catla contributes a major portion to the freshwater fish production in India. Most of the freshwater fish farms in India are situated in and around the agriculture fields or their source of freshwater is continuously in contact with the agriculture farms in which lot of pesticides, weedicides and insecticides are used. Keeping in view of these aspects, a study was planned to investigate sub-lethal effects of cypermethrin on haematological and biochemical parameters of $C$. catla fingerlings.

\section{Materials and methods}

Fish and husbandry

Catla (C. catla) fingerlings of $14 \pm 1 \mathrm{~g}$ were obtained from a fish seed farm at Pen, Raigarh District, Maharashtra, to the aquaculture laboratory complex, Central Institute of Fisheries Education (CIFE), Mumbai, India. Fishes were acclimatized for 2 weeks prior to the experiment. Chlorine-free tap water was used throughout the experiment. The physicochemical characteristics of the test water were as follows: temperature, $27 \pm 2.0^{\circ} \mathrm{C} ; \quad \mathrm{pH}, \quad 7.4 ;$ hardness, $80 \mathrm{mg} \mathrm{L}^{-1}$ (as $\mathrm{CaCO}_{3}$ ); alkalinity, $88 \mathrm{mg} \mathrm{L}^{-1}$ (as $\mathrm{CaCO}_{3}$ ); and dissolved oxygen concentration, 5.2$5.8 \mathrm{mg} \mathrm{L}^{-1}$.

\section{Cypermethrin}

The toxicant, Cypermethrin (10 EC) (cyano-(3-phenoxyphenyl)-methyl-(3-C2,2-dichloroethenyl)-2,2-dimethyl cyclopropane carboxylate), a synthetic pyrethroid obtained from Rallis India Pvt. Ltd. was used for determining the median lethal concentration on catla fingerlings at $96 \mathrm{~h}$. The $\mathrm{LC}_{50}$ value for cypermethrin was determined in the laboratory starting with range finding test to acute toxicity trials (Reish and Oshida 
1987). The 96-h $\mathrm{LC}_{50}$ was found to be $4.43 \mu \mathrm{g} \mathrm{L} \mathrm{L}^{-1}$. One-tenth concentration of $96 \mathrm{~h} \mathrm{LC}_{50}\left(0.443 \mu \mathrm{g} \mathrm{L}^{-1}\right)$ was selected for sub-lethal test trials.

\section{Experimental design}

Six rectangular plastic tanks $(100 \mathrm{~L})$ were arranged with continuous aeration. Randomly selected ninety catla fingerlings were equally divided into two groups (Group A and B). Both groups were equally divided to form their triplicate. Fishes of Group B were exposed to $1 / 10$ th concentration of $96-\mathrm{h}_{50}$ for a period of 60 days. Group A fishes were not exposed to pesticide and kept as control. Every day morning, the test solution (water containing $0.443 \mu \mathrm{g} \mathrm{L}^{-1}$ cypermethrin) of Group B was completely renewed with fresh one to maintain the required cypermethrin concentration of $0.443 \mu \mathrm{g} \mathrm{L}^{-1}$. Similarly, Group A tanks were also completely changed with normal water. The fishes were fed with feed @ $5 \%$ of their body weight twice a day throughout the experimental period.

\section{Haematological studies}

Blood was drawn from the caudal peduncle region using sterile 2-mL syringes rinsed first with $2.7 \%$ EDTA solution and was collected in small glass vials coated with $20 \mu \mathrm{L}$ of $2.7 \%$ EDTA solution. For the estimation of total erythrocyte count and total leucocyte count (TEC, Schaperclaus et al. 1991), $20 \mu \mathrm{L}$ of blood was mixed with $3,980 \mu \mathrm{L}$ of red blood cell (RBC) diluting fluid and white blood cell (WBC) diluting fluid (Dacies fluid) in a clean glass vial. The mixture was shaken well to suspend the cells uniformly in the solution. The cells were counted using a hemocytometer (Feinoptik, Blakenburg, Germany) and expressed as:

Number of $\mathrm{RBC} / \mathrm{mm}^{3}=N_{r} \times 10,000$

Number of $\mathrm{WBC} / \mathrm{mm}^{3}=N_{w} \times 500$

Where $N_{r}$ is the total number of red blood cells counted in five squares of the hemocytometer; 10,000 is the factor obtained after taking the initial dilution factor into consideration; $N_{w}$ denotes the total number of white blood cells counted in 4 squares of the hemocytometer; and 500 is the factor obtained after taking the initial dilution factor into consideration.

The blood haemoglobin content was analysed following the Cyanmethaemoglobin method using
Darbkins Fluid (Qualigens Diagnostics Kit, Mumbai, India). $20 \mu \mathrm{L}$ of blood was mixed with $5 \mathrm{~mL}$ of Darbkin's working solution. The absorbance was measured using a spectrophotometer at wavelength of $540 \mathrm{~nm}$. The final concentration was calculated after comparing with the standard. Haemoglobin content was expressed as gram/dl.

\section{Serum chemistry}

Blood was drawn from caudal region of fish without rinsing the syringe with anticoagulants and collected into clean and dry eppendorf tubes. The collected blood was allowed to clot for $45 \mathrm{~min}$ in inclined position at room temperature followed by $30-\mathrm{min}$ incubation at $4{ }^{\circ} \mathrm{C}$ and then centrifuged at $3000 \mathrm{~g}$ for $10 \mathrm{~min}$ at $4{ }^{\circ} \mathrm{C}$. Serum was collected into sterilized eppendorf tubes and analysed for the different serum parameters in AR. 601, Semi Automatic analyzer (Qualigens Diagnostic kit) using Qualigens kits. The parameters that were analysed by using this instrument were total protein (biuret method using buffered dye reagent and biuret reagent, Qualigens Diagnostic kits) and albumin (bromocresol green binding method, Qualigens Diagnostic kits).

\section{Enzyme assay}

At the end of experiment, brain, liver, muscle and gills were collected to carry out enzyme assay. Tissues of the five individuals from each replicate of a group were homogenized in chilled sucrose solution $(0.25 \mathrm{M})$ in Teflon-coated mechanical tissue homogenizer (Remi tissue homogenizer) and centrifuged at $5,000 \mathrm{~g}$ at $4{ }^{\circ} \mathrm{C}$ for $10 \mathrm{~min}$. The supernatant was used as an enzyme source for measuring enzymatic activity. All enzyme preparations were carried out on ice. Dilution of the sample was done as and when required.

Lactate dehydrogenase (LDH) (L-Lactate NAD + oxidoreductase; E.C.1.1.1.27) was assayed in $100 \mathrm{mM}$ phosphate buffer ( $\mathrm{pH} 7.5$ ) and 0.1 mM NADH. The reaction was initiated by adding $0.2 \mathrm{M}$ Na-pyruvate and monitored at $340 \mathrm{~nm}$ (Wroblewski and Ladue 1995). Alanine aminotransferase (ALT) (L-Alanine-2oxaloglutarate aminotransferase; E.C.2.6.1.2) was assayed with $200 \mathrm{mM}$ DL-alanine and $2 \mathrm{mM} \alpha$ ketoglutarate in $40 \mathrm{mM}$ phosphate buffer ( $\mathrm{pH} 7.4$ ) and estimated at $540 \mathrm{~nm}$ (Wotton 1964). Aspartate aminotransferase (AST) (Laspartate-2-oxaloglutarate 
aminotransferase, E.C.2.6.1.1) was assayed by the same procedure as for ALT except for the substrate, $200 \mathrm{mM}$ DL-aspartic acid instead of DL-alanine (Wotton 1964). Acetylcholine esterase (AChE) (Acetyl hydroxylase, E.C.3.1.1.7) was assayed by using a mixture of $0.07 \mathrm{M}$ phosphate buffer ( $\mathrm{pH} 7.2$ ), $4 \mathrm{mM}$ acetylcholine ( $\mathrm{pH} 4.0)$ and a substrate buffer mixture (1/10 dilution) (Hestrin 1949; Augustinsson 1957). The mixture was incubated at $37{ }^{\circ} \mathrm{C}$ for $30 \mathrm{~min}$. Alkaline hydroxylamine solution was used to terminate the reaction, and $\mathrm{HCl}(2: 1)$ was added. The colour developed by the addition of $10 \% \mathrm{FeCl}_{3}$ was measured at $540 \mathrm{~nm}$. Total adenosine triphosphatase (ATPase) (Adenosine triphosphate phosphohydrolase, E.C. 3.6.1.3) was assayed in a reaction mixture of $0.1 \mathrm{M}$ Tris- $\mathrm{HCl}$ buffer (pH 7.8), $100 \mathrm{mM}$ $\mathrm{NaCl}, 20 \mathrm{mM} \mathrm{KCl}, 3 \mathrm{mM} \mathrm{MgCl} 2$ and $5 \mathrm{mM}$ ATP. The mixture was incubated for $15 \mathrm{~min}$, and then the reaction was terminated by means of $10 \%$ trichloroacetic acid (Post and Sen 1967). Phosphate liberated was estimated at $660 \mathrm{~nm}$ (Fiske and Subbarow 1925). A similar reaction mixture was used for the estimation of magnesium adenosine triphosphatase $\left(\mathrm{Mg}^{2+}\right.$-ATPase) activity (Magnesium Transporting ATPase, E.C. 3.6.3.1) except for reaction termination, $0.1 \mathrm{~mL}$ of $1 \mathrm{mM}$ of ouabain was used. Sodium-potassium adenosine triphosphatase $\left(\mathrm{Na}^{+}, \mathrm{K}^{+}\right.$-ATPase) activity was estimated by subtracting $\mathrm{Mg}^{2+}$-ATPase activity from total ATPase activity. Total protein contents were analysed from the supernatant of all organ samples (Lowry et al. 1951) for calculating enzyme activities. All the colorimetric assays were carried out using UVVIS spectrophotometer (E-Merck, Germany).

\section{Statistical analysis}

The data obtained from 60-day experiment on sublethal toxicity test were statistically analysed by $t$ test. A significance level of $P \leq 0.05$ was used.

\section{Results}

The TEC, TLC, haemoglobin content and haematocrit levels were significantly reduced $(P \leq 0.05)$ in cypermethrin-exposed group of fishes when compared to control group after 60 days (Table 1). All the serum parameters viz. total protein, albumin, globulin contents and albumin-globulin ratio were significantly decreased $(P \leq 0.05)$ in Group B fishes compared to Group A fishes (Table 2). The LDH activity in muscle of Group B fishes was significantly reduced $(P \leq 0.05)$ by $36.84 \%$ in compare to Group A fishes (Table 3). AChE activity in brain was inhibited in cypermethrin-exposed fish $(0.39 \pm 0.02)$ in comparison with control fish $(0.59 \pm 0.03)$ (Table 3$)$. The activities of ALT and AST enzymes in liver of fish exposed to cypermethrin were significantly enhanced $(P \leq 0.05)$ by $30.16 \%$ and $32.47 \%$, respectively, in comparison with control group of fishes (Table 3). The activities of membrane transport enzymes in gill tissues of catla are given in Table 4. A significant reduction $(P \leq 0.05)$ in the level of adenosine triphosphatase, ATPase, $\mathrm{Na}^{+}, \mathrm{K}^{+}$-adenosine triphosphatase and $\mathrm{Mg}^{2+}$-adenosine triphosphatase activities in gill (42.56, 41.58 and $44.78 \%$, respectively) of cypermethrin-exposed fish was observed compare to the control.

\section{Discussion}

Haematological and biochemical profiles of blood can provide important information about the internal environment of the organism ( $\mathrm{Li}$ et al. 2010). In the present study, exposure of fishes to sub-lethal concentration of cypermethrin showed remarkable alterations in haematological and physiological stress markers. The significant decrease in total erythrocyte counts, total leucocyte count, haemoglobin concentration and haematocrit value was observed in fishes exposed to a sub-lethal concentration of cypermethrin for 60 days. Decrease in haemoglobin concentration, TEC and haematocrit may be the indicator of anaemia. The similar finding was reported in Cyprinus carpio (Dorucu and Girgin 2001) and Labeo rohita (Das and Mukherjee 2003) exposed to cypermethrin. Jee et al. (2005) observed reduction in erythrocytes count, haemoglobin concentration and haematocrit value in Korean rockfish (Sebastes schlegeli) exposed to cypermethrin and they opined that it was because of the destructive action of cypermethrin on cell membrane. They also reported that decline in RBC count, haemoglobin concentration and haematocrit value presumably reflected erythrocyte haemolysis and/or irreparable damage of gill morphology and function. The decrease in haemoglobin concentration may be because of either an increase in the rate at which 
Table 1 Alteration in haematological parameters of $C$. catla exposed to sub-lethal concentration of cypermethrin for 60 days

\begin{tabular}{lllrr}
\hline Treatment & TEC $\left(\times 10^{6}\right.$ cells $\left./ \mathrm{mm}^{3}\right)$ & TLC $\left(10^{4}\right.$ cells $\left./ \mathrm{mm}^{3}\right)$ & Haemoglobin $(\mathrm{g} \%)$ & Haematocrit $(\%)$ \\
\hline Group A & $2.68^{\mathrm{a}} \pm 0.05$ & $4.18^{\mathrm{a}} \pm 0.10$ & $10.57^{\mathrm{a}} \pm 0.35$ & $33.17^{\mathrm{a}} \pm 1.16$ \\
Group B & $2.11^{\mathrm{b}} \pm 0.05$ & $3.36^{\mathrm{b}} \pm 0.13$ & $6.60^{\mathrm{b}} \pm 0.21$ & $17.17^{\mathrm{b}} \pm 0.22$ \\
\hline
\end{tabular}

Values are expressed as mean \pm SE. Mean value $(n=3)$ in column bearing different superscripts varies significantly $(P \leq 0.05)$

Table 2 Change in serum biochemical parameters of $C$. catla exposed to sub-lethal cypermethrin concentration for 60 days

\begin{tabular}{lllll}
\hline Treatment & Total protein $(\mathrm{g} / \mathrm{dl})$ & Albumin $(\mathrm{g} / \mathrm{dl})$ & Globulin $(\mathrm{g} / \mathrm{dl})$ & Albumin-globulin ratio \\
\hline Group A & $4.48^{\mathrm{a}} \pm 0.28$ & $2.09^{\mathrm{a}} \pm 0.08$ & $2.40^{\mathrm{a}} \pm 0.19$ & $0.88^{\mathrm{a}} \pm 0.02$ \\
Group B & $2.77^{\mathrm{b}} \pm 0.20$ & $1.03^{\mathrm{b}} \pm 0.02$ & $1.73^{\mathrm{b}} \pm 0.18$ & $0.61^{\mathrm{b}} \pm 0.06$ \\
\hline
\end{tabular}

Values are expressed as mean \pm SE. Mean value $(n=3)$ in column bearing different superscripts varies significantly $(P \leq 0.05)$

Table 3 Alterations in enzyme activity of anaerobic pathways (lactate dehydrogenase in muscle), neurotransmission (acetyl choline esterase in brain) and protein metabolism (alanine aminotransferase and aspartate aminotransferase in liver) of $C$. catla exposed to sub-lethal concentration of cypermethrin for 60 days

\begin{tabular}{llllr}
\hline Treatment & LDH activity & AChE activity & ALT activity & AST activity \\
\hline Group A & $0.38^{\mathrm{a}} \pm 0.01$ & $0.59^{\mathrm{a}} \pm 0.03$ & $2.42^{\mathrm{b}} \pm 0.10$ & $8.13^{\mathrm{b}} \pm 0.37$ \\
Group B & $0.24^{\mathrm{b}} \pm 0.02$ & $0.39^{\mathrm{b}} \pm 0.02$ & $3.15^{\mathrm{a}} \pm 0.16$ & $10.77^{\mathrm{a}} \pm 0.54$
\end{tabular}

Values are expressed as mean \pm SE. Mean value $(n=3)$ in column bearing different superscripts varies significantly $(P \leq 0.05)$

Enzyme activities are expressed as follows: $\mathrm{LDH}$ as $\mu \mathrm{mol}$ of pyruvate utilized $/ \mathrm{mg}$ protein/min, AchE as $\mu \mathrm{mol}$ of acetyl choline hydrolyzed/mg protein/min at $37^{\circ} \mathrm{C}$, ALT as nmol of sodium pyruvate released $/ \mathrm{mg}$ protein/min at $37^{\circ} \mathrm{C}$, AST as nmol of oxaloacetate released $/ \mathrm{mg}$ protein $/ \mathrm{min}$ at $37^{\circ} \mathrm{C}$

Table 4 Alterations in the activity of membrane transport enzyme (adenosine triphosphatase, ATPase, $\mathrm{Na}^{+}, \mathrm{K}^{+}$-adenosine triphosphatase and $\mathrm{Mg}^{2+}$-adenosine triphosphatase

\begin{tabular}{llll}
\hline Treatment & Total ATPase activity & $\mathrm{Mg}^{2+}$ ATPase activity & $\mathrm{Na}^{+}-\mathrm{K}^{+}$ATPase activity \\
\hline Group A & $68.04^{\mathrm{a}} \pm 4.04$ & $46.25^{\mathrm{a}} \pm 2.04$ & $21.79^{\mathrm{a}} \pm 2.02$ \\
Group B & $39.08^{\mathrm{b}} \pm 2.93$ & $27.02^{\mathrm{b}} \pm 1.30$ & $12.05^{\mathrm{b}} \pm 1.68$ \\
\hline
\end{tabular}

Values are expressed as mean \pm SE. Mean value $(n=3)$ in column bearing different superscripts varies significantly $(P \leq 0.05)$

haemoglobin is destroyed or a decrease in the rate of its synthesis.

The change in differential leucocyte counts is recognised as sensitive indicator of environmental stress (Cole et al. 2001). In the present study, TLC was significantly reduced in fishes exposed to sub-lethal dose of cypermethrin. Similar findings were reported by Dorucu and Girgin (2001) in Cyprinus carpio and Nath and Banerjee (1996) in Heteropneustes fossilis following poisoning with cypermethrin. $\mathrm{Li}$ et al. (2011) also reported decrease in TLC in rainbow trout exposed to propiconazole. This might be due to the destruction of haematopoeitic tissue or reduced activity) as $\mu \mathrm{g}$ of phosphorus/mg protein/min at $37{ }^{\circ} \mathrm{C}$ in gill of $C$. catla exposed to sub-lethal concentration of cypermethrin for 60 days 
The albumin has been reported to be an osmoregulator of blood volume, an easily available protein reserve and a protein transporter (Anderson et al. 1979). Dutta (1996) described that hyperactivity caused by deltamethrin (a synthetic pyrethroid) may lead to the utilization of this easily accessible protein reserve-fraction containing albumin, resulting in a decreased quantity. Another possible reason for the lowered amount of albumin may be a decreased albumin synthesis in the hepatocytes (Dutta et al. 1993). In the present study, similar findings have been noticed in fishes exposed to sub-lethal concentration of cypermethrin. The minimum albumin-globulin ratio in Group B fishes may be mainly due to heavy breakdown of albumin under cypermethrin stress. Nayak et al. (2004) reported a similar result upon permethrin (a pyrethroid insecticide) exposure to Labeo rohita. According to their opinion, the reduction in total serum protein, albumin, globulin and albumin-globulin ratio was strong indicators of an immunosuppressive effect of the pesticide.

Toxicants have been shown to cause alterations in the activities of many enzymes concerning to cellular energy metabolism (Sebert et al. 1993; Almeida-val et al. 1995). In the present investigation, alanine and aspartate amino transaminase activities were significantly $(P \leq 0.05)$ enhanced in liver tissue of fishes, which were exposed to sub-lethal concentration of cypermethrin. Similar increase in AST and ALT activities in hepatic and gill tissues of Clarias batrachus on the exposure to cypermethrin was reported by Begum (2005). Sharma (1999) opined that the rise in the activities of transaminases suggests enhanced protein catabolism and hepatocellular damage in the organism. Similarly, the increase in transaminase activity in catla exposed to sub-lethal concentration of cypermethrin might be due to the enhanced protein catabolism and hepatocellular damage.

In the present study, inhibition in the muscle LDH activity was observed when fishes were exposed to sub-lethal concentration of cypermethrin. The decrease in LDH activity suggests a reduction in the conversion of lactate to pyruvate, thereby leading to the accumulation of lactic acid. The decrease in LDH activity with a consequent increase in the levels of lactic acid suggests the predominance of anaerobic segment, glycolysis. Sivakumari et al. (1997), while working on cypermethrin toxicity, have explained that changes in dehydrogenase activity in pesticide-treated fishes may be due to severe cellular damage leading to the release of these enzymes and impaired carbohydrate and protein metabolism.

Acetylcholine esterase (AChE) is one of the most widely used enzymes as a biomarker for environmental pollution. Acetylcholine is synthesized in nervous tissue by enzyme choline esterase. Acetylcholine is rapidly destroyed by choline esterase, a group of related enzymes that are hydrolytic in action (Stowe 1969). The highly decreased brain AChE activity shown by Group B fishes might be due to the inhibitory effect of cypermethrin. Our results are in agreement with those obtained in Labeo rohita (Marigoudar et al. 2009; Das and Mukherjee 2003) and Channa punctatus (Kumar et al. 2009), where exposure to cypermethrin showed reduced brain AChE activity.

ATPases, a membrane bound enzyme group, are responsible for the movements of different ions across the cell membrane. In fish, various toxicants enter through gill surface by diffusion. An interaction with the membranes may disrupt the osmotic and ionic regulation of the cell membrane permeability, mainly due to the inactivation of the ATPases in the brancheal epithelial cells (Chhaya et al. 1997). The gill ATPase activity had been used as a sensitive biomarker for the assessment of pollutant-induced damage to the osmoregulatory and acid-base regulatory systems in the gills (Stagg et al. 1992).

The activities of total ATPase, sodium-potassium ATPase and magnesium ATPase were significantly decreased in gill tissue of fishes exposed to sub-lethal concentration of cypermethrin (Group B). Similar to this study, inhibition of the gill ATPase activity upon exposure to cypermethrin is well documented in Cirrhinus mrigala (Prashanth and David 2010) and Labeo rohita (Das and Mukherjee 2003). The decrease in their activities indicates the demolition of cellular ionic regulations in the organ of fish as reported earlier (Renfro et al. 1974; Schmidt Nielson 1975). This disruption may be due to toxic effect of cypermethrin on passive movement of ions (Chandravathy and Reddy 1995). Further, greater imbalance caused to the gill structures may also be probable reason for changes observed in ATPases activities. At cellular level, pesticide interacts with the ATPases and the interaction mainly depends on the cell surface area (David 1995). The inhibition of $\mathrm{Na}^{+}-\mathrm{K}^{+}$ATPase is probably due to the disturbance in $\mathrm{Na}^{+}-\mathrm{K}^{+}$pump, resulting in an uncontrollable entry of $\mathrm{Na}^{+}$ions into the cell along 
the concentration gradient, with water molecule following along the osmotic gradient. This process may cause swelling of the cell and finally membrane ruptures (Chandravathy and Reddy 1995). The inhibition of $\mathrm{Mg}^{2+}$ ATPase, an ion-specific ATPase, could be attributed to the loss of sodium and potassium ions due to cellular leakage into the body fluids. Nonavailability of substrates like ATP molecules may also result in the inhibition of these ion-specific ATPases (Chandravathy and Reddy 1995).

Finally, from the present investigation, it can be concluded that the exposure of $C$. catla fingerlings to the sub-lethal concentration of cypermethrin caused significant alterations in its haematological and biochemical parameters. This kind of stressor for a longer period might substantially reduce the growth and immunity of exposed fishes and ultimately it may affect the aquaculture production.

Acknowledgement The first author is grateful to The Director, CIFE, Mumbai, for providing facilities for carrying out the work. The financial support in terms of institutional fellowship by Indian Council of Agricultural Research (ICAR) and Central Institute of Fisheries Education (CIFE) is highly acknowledged.

\section{References}

Almeida-Val VMF, Farias IP, Silva MNP, Duncan WP, Val AL (1995) Biochemical adjustments to hypoxia by Amazon cichlids. Braz J Med Biol Res 28:1257-1263

Anderson DP, Robertson BS, Dixon OW (1979) Plaque-forming cells and humoral antibody in rainbow trout (Salmo gairdneri) induced by immersion in a Yersinia ruckeri O-antigen preparation. J Fish Res Board Can 36(6):636639

Augustinsson KB (1957) Assay methods for cholinesterases. Methods Biochem Anal 5:1-63

Begum G (2005) Toxicity of cypermethrin on total lipids and free fatty acids in liver, muscle, kidney and ovary of Clarias batrachus $(\mathrm{L})$ and recovery response. Toxicol Environ Chem 87:253-260

Braidwood JC, Hart JL (1998) Control of sea lice in fish. ASFA, pp 1999 (CD-ROM)

Carriquiriborde P, Diaz J, Mugni H, Bonetto C, Ronco AE (2007) Impact of cypermethrin on stream fish populations under field-use in biotech-soybean production. Chemosphere 68:613-621

Chandravathy M, Reddy SLN (1995) In vivo alterations in the activities of ion-specific ATPases in the tissue of Anabas scandens associated with sub lethal lead nitrate toxicity and recovery responses during post-exposure period. J Environ Biol 16:301-304
Chhaya J, Thaker J, Mansuri AP, Kundu R (1997) Textile dyeing and printing industry effluent induced changes in activity of few ATPases in the gill and intestine of mudskipper, Periophthalumus dipes. Poll Res 16:93-97

Cole MB, Arnold DE, Watten BJ, Krise WF (2001) Haematological and physiological responses of brook charr, to untreated and limestone-neutralized acid mine drainage. J Fish Biol 59:79-91

Crane M, Maltby L (1991) The lethal and sublethal responses of Gammarus pulex to stress: sensitivity and sources of variation in an in situ bioassay. Environ Toxicol Chem 10:1331-1339

Das BK, Mukherjee SC (2003) Toxicity of cypermethrin in Labeo rohita fingerlings: biochemical, enzymatic and haematological consequences. Comp Biochem Physiol 134C:109-121

David M (1995) Effect of fenvalerate on behavioral, physiological and biochemical aspects of freshwater fish Labeo rohita. PhD thesis, SK University, Anantapur, Andra Pradesh, India

Dorucu M, Girgin A (2001) The effect of cypermethrin on some haematological parameters of Cyprinus carpio. Aquac Intern 9:183-187

Dutta HM (1996) A composite approach for evaluation of the effects of pesticides on fish. In: Munshi JSD, Dutta HM (eds) Fish morphology: horizon of new research. New Hampshire Science Publishers Inc and Oxford IBH, Lebanon, pp 249-269

Dutta HM, Adhikari S, Singh NK, Roy PK, Munshi JS (1993) Histopathological changes induced by malathion in the liver of a freshwater catfish, Heteropneustes fossilis (Bloch). Bull Environ Contam Toxicol 51:895-900

Fiske CH, Subbarow Y (1925) The colorimetric determination of phosphorus. J Biol Chem 66:375-400

Hart J, Thacker J, Braidwood J, Fraser N, Matthews J (1997) Novel cypermethrin formulation for the control of sea lice on salmon (Salmo salar). Vet Rec 140:179-181

Hestrin L (1949) The reaction of Acetyl choline esters and other carboxylic acid derivatives with hydroxylamine and its analytical application. J Biol Chem 180:249-261

Hill IR (1989) Aquatic organisms and pyrethroids. J Pesticide Sci 27:429-465

Jayswal AP (1989) Management of American bollworm on cotton in Andhra Pradesh. Indian Farm 17:6-7

Jee LH, Masroor F, Kang JC (2005) Responses of cypermethrininduced stress in haematological parameters of Korean rockfish, Sebastes schlegeli (Hilgendorf). Aquac Res 36: 898-905

Jin H, Webster GRB (1998) Persistence, penetration and surface availability of cypermethrin and its major degradation products in elm bark. J Agric Food Chem 46:2851-2857

Kumar A, Sharma B, Pandey RS (2007) Preliminary evaluation of the acute toxicity of cypermethrin and $k$-cyhalothrin to Channa punctatus. Bull Environ Contam Toxicol 79:613-616

Kumar A, Rai DK, Sharma B, Pandey RS (2009) $\lambda$-cyhalothrin and cypermethrin induced in vivo alterations in the activity of acetyl cholinesterase in Channa punctatus (Bloch). Pesti Biochem Phys 93:96-99 
Kumari B, Madan VK, Kathpal TS (2008) Status of insecticide contamination of soil and water in Haryana, India. Environ Monit Assess 136:239-244

Li ZH, Li P, Randak T (2010) Ecotoxicological effects of shortterm exposure to a human pharmaceutical Verapamil in juvenile rainbow trout (Oncorhynchus mykiss). Comp Biochem Phy C 152:385-391

Li ZH, Velisek J, Grabic R, Li P, Kolarova J, Randak T (2011) Use of haematological and plasma biochemical parameters to assess the chronic effects of a fungicide propiconazole on a freshwater teleost. Chemosphere 83:572-578

Lowry OH, Ronebrough NJ, Farr AL, Randall RJ (1951) Protein measurement with folin phenol reagent. J Biol Chem 193:265-276

Marigoudar SR, Nazeer Ahmeda R, David M (2009) Cypermethrin induced: in vivo inhibition of the acetylcholinesterase activity in functionally different tissues of the freshwater teleost, Labeo rohita (Hamilton). Toxicol Environ Chem 91:1175-1182

Miren P, Cajaraville MJ, Bebianno JB, Cinta P, Carmen S, Aldo $\mathrm{V}$ (2000) The use of biomarkers to assess the impact of pollution in coastal environments of the Iberian peninsula: a practical approach. Sci Total Environ 247:295-311

Mukherjee SC, Das BK, Murjani G, Pattnaik P, Swain P (2000) Problems of argulosis in fresh water fishes and a suitable control Abst. Fifth Indian Fisheries Forum. Central Institute of Freshwater Aquaculture. Kausalyaganga, Bhubaneswar, p 122

Nath R, Banerjee V (1996) Effect of pesticides methyl parathion and cypermethrin on the air breathing fish- Heteropneustes fossilis (Bloch). Environ Ecol 14:163-165

Nayak AK, Das BK, Kohli MPS, Mukherjee SC (2004) The immunosuppressive effect of $\alpha$-permethrin on Indian major carp, rohu (Labeo rohita Ham.). Fish Shellfish Immunol $16: 41-50$

Post RL, Sen AK (1967) Sodium and potassium-stimulated ATPase. In: Colowick SP, Kaplan NO (eds) Methods in enzymology, vol 10. Academic Press, New York, pp 762768

Prashanth MS, David M (2010) Impact of Cypermethrin on $\mathrm{Na}^{+}-\mathrm{K}^{+}, \mathrm{Ca}^{2+}$ and $\mathrm{Mg}^{2+}$ ATPases in Indian Major Carp, Cirrhinus mrigala (Hamilton). Bull Environ Contam Toxicol 84:80-84

Reish DL, Oshida PA (1987) Manual of method in aquatic environment research. Part 10 - Short-term static bioassay. FAO Fisheries Technical Paper. 247. FAO, Rome, pp 1-62

Rendon-von Osten J, Ortiz-Arana A, Guilhermino L, Soares AMVM (2005) In vivo evaluation of three biomarkers in the mosquito fish (Gambusia yucatana) exposed to pesticides. Chemosphere 58:627-636

Renfro JLB, Schmidt Nielson D, Miller DB, Allens J (1974) Methyl mercury and inorganic mercury uptake, distribution and effect on osmoregulatory mechanisms in fishes. In:
Vernberg FJ, Vernberg WB (eds) Pollution and physiology of marine organisms. Academic Press, San Diego, p 317

Schaperclaus W, Kulow H, Schreckenbach K (1991) Haematological and serological technique. In: Kothekar VS (ed) Fish disease, vol 1, 2nd edn. Oxonian Press, Gulab Primlani, New Delhi, pp 71-108

Schmidt Nielson B (1975) Osmoregulation. Effect of salinity and heavy metal. Fed Proc Fed Am Soc Exp Biol 33:2137-2146

Sebert P, Simon B, Barthelemy L (1993) Hydrostatic pressure induces a state resembling histotoxic hypoxia in Anguilla anguilla. Comp Biochem Physiol 105B:255-258

Sharma B (1999) Effect of carbaryl on some biochemical constituents of the blood and liver of $C$. batrachus, a fresh water teleost. J Toxicol Sci 24:157-164

Shashikumar S, Rajini PS (2010) Cypermethrin-induced alterations in vital physiological parameters and oxidative balance in Caenorhabditis elegans. Pest Biochem Physiogn 97:235-242

Siegfried BD (1993) Comparative toxicity of pyrethroid insecticides to terrestrial and aquatic insects. Environ Toxicol Chem 12:1683-1689

Sivakumari K, Manavalaramanujam R, Ramesh M, Lakshmi R (1997) Cypermethrin toxicity; sublethal effects on enzyme activities in a fresh water fish, Cyprinus carpio var. communis. J Environ Biol 18:121-125

Sommerville C (1995) Latest weapon in the war on lice. Fish Farmer 18:53-55

Stagg RM, Rusin J, Brown F (1992) Na +, K + -ATPase activity in the gills of the flounder (Platichthys flesus) in a relation to mercury contamination in the Firth of Forth. Mar Environ Res 33:255-266

Stowe CM (1969) Cholinergic (parasympathomiatic) drugs: drug acting on autonomic nervous system. In: Jones M (ed) Veterinary pharmacology and therapeutics. Oxford and IBH publishing co., New Delhi, pp 265-350

Thrall MA (2004) Veterinary hematology and clinical chemistry. Williams and Wilkins, Philadelphia, pp 277-289

Vani T, Saharan N, Mukherjee SC, Ranjan R, Kumar R, Brahmchari RK (2011) Deltamethrin induced alterations of hematological and biochemical parameters in fingerlings of Catla catla (Ham.) and their amelioration by dietary supplement of vitamin C. Pestic Biochem Physiol 101: $16-20$

Vijverberg HPM, Van den Bercken J (1990) Neurotoxicological effects and the mode of action of pyrethroid insecticides. Crit Rev Toxicol 21(2):105-126

Wotton IDP (1964) Microanalysis in medical biochemistry. 4th edn. J. \& A. Churchill, London, pp 101-107

Wroblewski L, Ladue JS (1995) LDH activity in blood. Proc Soc Exp Biol Med 90:210-213 